(с) Ружанська В.О., Сивак В.Г., Лозинська М.С., Жебель В.М. УДК: [612.172+577.112]:575.22-055.1

\title{
ГАЛЕКТИН-3 ЯК МАРКЕР ФУНКЦІЇ МІОКАРДУ У ЧОЛОВІКІВ 40-60 РОКІВ БЕЗ СЕРЦЕВО-СУДИННОЇ ПАТОЛОГІї, НОСІЇВ ПОЛІМОРФНИХ ГЕНІВ АТ1Р*
}

\author{
Ружанська В.О., Сивак В.Г., Лозинська М.С., Жебель В.М.
}

Вінницький національний медичний університет ім. М.І.Пирогова, м.Вінниця

В работе изучались концентрации галектина-3 и МНП, показатели центральной и системной гемодинамики у носителей полиморфных генов АT1P и структурно-функциональные показатели сердца у мужчин без сердечнососудистой патологии $(n=79)$ которые проживают территории Подольского региона. Генотипирование гена AT1P проводилось при помощи полимеразно-цепной реакции. Уровень галектина-3 и МнП определяли с помощью метода иммуноферментного анализа. Выяснилось, что у практически здоровых мужчин жителей Подольского региона доминирует генотип А1166А. Всё же уровень галектина-3 и МнП в исследуемой популяции существенно не зависел от носительства конкретного варианта гена AT1P.

Ключевые слова: полиморфизм гена рецептора ангиотензина II типа 1 (AT1P), галектин-3, мозговой натрийуретический пептид, артериальное давление..

\section{Вступ}

Вікова перебудова структури серця, розширення його камер, зменшення еластичності кардіальних клітин та зниження рухомості серцевих структур, затримка рідини і ремоделювання судин, що підвищує навантаження на лівий шлуночок (ЛШ), нейрогуморальна атака $є$ одними з можливих ланок патогенезу серцевої недостатності особливо на тлі серцево-судинної патології [13]. Для лікарів всього світу пошук ефективного скринінгового інструменту асимптомної дисфункції ЛШ, стратифікації ризику та загального прогнозу, якості життя слугує предметом багатьох наукових аналізів та обговорень. Одним із напрямків таких пошуків $є$ застосування сучасних біомаркерів стану міокарду. До теперішнього часу визначено велику кількість (понад 100) біомаркерів, які мають тісний зв'язок з погіршенням функції міокарду, проте інтерпретація таких аналізів і їх клінічного значення дуже часто $€$ недостатньою. 3 них в клінічній практиці для діагностики гострої і загострення хронічної серцевої недостатності (XCH) найбільш широко застосовують системи предствників натрійуретичних пептидів (НУП), а саме мозковий натрійуретичний пептид (МНП). НУП - група циркулюючих в крові гормонів, що регулюють водносольовий гомеостаз та артеріальний тиск (АТ). В фрізіологічних умовах так і при формуванні серцевосудинної патології НУП відіграють важливу роль в регуляції структурно-фрунціонального стану серцевосудинної патології. МНП вважають серцевим гормоном, що регулює об'єм рідини в організмі і АТ, зменшує переднавантаження та постнавантаженя на серце. Його дія призводить до збільшення швидкості клубочкової фрільтрації, натрійурезу, блокаді ренінангіотензин-альдостеронової системи, придушення спонтанної та індукованої ангіотензином II спраги, гальмуванню виділення аргініну і вазопресину, зменшенню вазоконстрикторної дії ендотеліну-1, а також симпатичної іннервації судин. Внаслідок цього відбувається зниження тиску в порожнинах серця, тонусу судин, загального периферичного опору і АТ [8]. У багатьох дослідженнях показано, що активація синтезу МНП відбувається у пацієнтів з дисфункцією ЛШ, як 3 асимптомною, так і з клінічно вираженою дисфункцією міокарду, незалежно від її причини [5]. Встановлено позитивний лінійний зв'язок між рівнем МНП та кінцево-діастолічним тиском у ЛШ [6] і відповідно розвитком діастолічної дисфунції міокарда [18], що дозволяє розглядати МНП, як можливий маркер стану функції серця. Однак, в той же час прогностичне значення даного маркеру для стратифікації ризику на сьогодні вважається недостатнім, у зв'язку з чим для визначення більш точного прогнозу у хворих з міокардіальною дисфункцією доцільно як сумісне використання відомих біомаркерів, так і пошук нових.

Одним з таких біомаркерів $є$ галектин-3, який являється представником родини галектинів, $€$ індуктором міграції макрофрагів, проліферації фібробластів та синтезу колагену. Галектин-3 може бути одним з можливих покажчиків синдрому серцевої недостатності, адже відображає активність процесу запалення та фіброзу, практично не виявляється у кардіоміоцитах, тоді як фрібробласти міокарда експресують його високі рівні [17]. При потраплянні у міокард він через паракринний ефект стимулює швидке збільшення міофібробластів та вивільнення проколагену 1 у позаклітинну матрицю, що призводить до серцевого фіброзу [23]. Експресія галектину-3 має достовірну кореляцію з ФВ ЛШ підвищується у пацієнтів зі зниженою та збереженою фракцією викиду лівого шлуночка не залежно від етіології міокардіальної дисфункції, коли ще немає клінічних проявів [16]. Ці дані можуть свідчити про більш виражений фіброз міокарду у осіб зі зниженою ФВ, що призводить до прогресування діастолічної дисфункції ЛШ [4]. Рівень галектину-3 у хворих на $\mathrm{XCH}$ на тлі артеріальної гіпертензії був у 1,5 разів вищим порівняно з хворими без такої відповідно [14]. У плазмі крові рівень галектину-3 найбільше корелює 3 високим ризиком кардіоваскулярної смертності та повторної госпіталізації у пацієнтів з ХCH [20]. Галектин3 був затверджений, як біомаркер з незалежним прогностичним значенням у пацієнтів з гострою та хронічною серцевою недостатністю, а також з його допомогою можна спрогнозувати короткочасну (60-денну) смертність, адже біомаркер МНП краще використовувати для довготривалого прогнозу (4 роки) [26]. 3

* Цитування при атестації кадрів: Ружанська В.О., Сивак В.Г., Лозинська М.С., Жебель В.М. Галектин-3 як маркер функції міокарду у чоловіків 40-60 років без серцево-судинної патології, носіїв поліморфних генів АТ1Р.// Проблеми екології і медицини. - 2018. - T. 22, № 1-2. - С. 33-37. 
2013 року галектин-3 включений до чинної клінічної угоди Американської асоціації серця 3 профрілактики та лікування $\mathrm{XCH}$, як додатковий маркер стратифікації високого ризику виникнення несприятливих клінічних результатів (смерть і повторна госпіталізація) [27].

Вищезгадані патологічні процеси в міокарді маркером яких $є$ МНП та галектин-3, стимулюються, як відомо, норадреналіном, альдостероном та ангіотензином II [7]. Останній реалізує свій вплив через АT1Р, отже, поліморфізм цех рецепторів може стати «умовним тригером» регуляції рівня МНП та галектину-3.

Результати багатьох експериментальних та клінічних досліджень дозволяють стверджувати, що у патогенезі дисфункції міокарду одна з основних ланок активація компонентів ренін-ангіотензин-альдостеронової системи (РАAC) та її ефекторного гормону ангіотензину II [12]. Ген АT1P картований у 3-й хромосомі (3q21-3q25), він містить 5 екзонів і на сьогодні описано близько 16 структурних поліморфрізмів цього гена. Проте, виявилося, що саме поліморфізм-заміна у положенні 1166 аденіну (A) на цитозин (C) пов'язаний 3 функціональною активністю АТ1P [21]. Для представників Подільського регіону України показаний зв'язок розвитку ГХ з поліморфізмом АТ1Р серед чоловіків 40-60 років, у ході досліджень встановлено, що для носіїв алелі C ймовірність розвитку вираженої ексцентричної ГЛШ та діастолічної дисфункції серця в процесі перебігу ГХ є суттєво вищою, ніж для носіїв лише алелі $A[3,9,11]$. Вірогідність захворіти на гіпертонічну хворобу при наявності у пацієнта генотипу А1166C підвищується в 1,3 рази [23].

Таким чином, знаходячи можливі асоціативні зміни носійства поліморфних генів АТ1P та рівнів галектина-3 і МНП у осіб, які не мають серцево-судинної патології можливо в подальшому опиратись на ці маркери в прогнозуванні структурних змін міокарду у хворих з ГХ та ХCH аналогічного віку та статі.

Раніше подібні дослідження в Україні не проводились. В статті представлений перший етап у вигляді результатів обстеження чоловіків 40-60 років без серцево-судинної патології, мешканців Подільського регіону України.

Мета роботи: вивчити рівні біомаркерів галектину3 і МНП в плазмі крові та відповідний стан структурно-функціональних показників міокарду у чоловіків 4060 років без ознак серцево-судинної патології, носіїв поліморфних генів АТ1Р.

\section{Матеріали і методи дослідження}

При проведенні дослідження було обстежено 79 чоловіків 40-60 років без ознак серцево-судинної патології, що проживають на території Подільського регіону. Середній вік обстежуваних становив 57,06 $\pm 0,50$ років. Усі чоловіки знаходились на обстеженні у Вінницькому обласному спеціалізованому клінічному диспансері радіаційного захисту населення МО3 України i Військово-медичному клінічному центрі Центрального регіону Військово-повітряних сил України, а також спостерігались амбулаторно з грудня 2013 року по липень 2014 року. Усі чоловіки, що увійшли в групу дослідження на момент огляду скарг 3 боку серцево-судинної системи не пред'являли і не мали об'єктивних патологічних ознак. Для визначення алелей поліморфної ділянки (А1166C) гена АТ1P використовувався метод полімеразної ланцюгової реакції. Генотипування гена АT1P проводилось спільно 3 НДІ генетичних та імунологічних основ розвитку патології та фрармакогенетики ВДНЗУ «Українська медична стоматологічна академія» (м. Полтава, керівник професор Кайдашев І.П.). Для визначення алелей поліморфної ділянки (A1166C) гена АТ1Р проводилось виділення геномної ДНК із лейкоцитів венозної крові. Концентрація МНП у плазмі крові у обстежуваних визначалась за допомогою імуноферментного методу на стриповому імуноферментному аналізаторі "Нumareader single" (Німеччина) при довжині хвилі 450 нм та диференційним фрільтром 630 нм. Для визначення плазмової концентрації МНП використовували стандартний набір фрірми "Peninsula laboratories Inc." (США). Концентрацію галектину-3 в плазмі крові обстежуваних визначали методом імуноферментного аналізу за допомогою апарату «Stat Fact 330» при довжині хвилі 450 нм та диференційним фрільтром 630 нм. Для визначення плазмової концентрації галектину-3 використовували стандартний набір реактивів фрірми «Bender MedSystems $\mathrm{GmbH»} \mathrm{(Австрія).} \mathrm{Було}$ проведено перевірку розподілу частот поліморфних генів у популяції відповідно до закону рівноваги ХардіВайнберга за допомогою калькулятора ген експерт для розрахунку ряду статистичних параметрів у дослідженнях «випадок-контроль», що використовують SNP (Государственный Научный Центр Российской Федерации “ГосНИИ генетика", gen-exp.ru). Оцінку параметрів системної та внутрішньосерцевої гемодинаміки проводили за допомогою УЗД серця, яке виконувалось на ехограмі "Sim5000 Plus". Маса міокарда лівого шлуночка (ММЛШ) - розраховувалась за формулою Penn Convention, індекс маси міокарду лівого

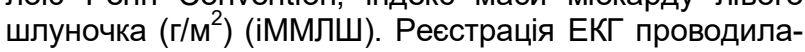
ся за загальноприйнятою методикою у 12 стандартних відведеннях. Вимірювання артеріального тиску здійснювали згідно рекомендаціям експертів ВООЗ. Математичну обробку виконували на персональному ком'ютері з використанням стандартного статистичного пакету STATISTICA 10,0.

\section{Результати та їх обговорення}

В обраній популяції осіб було визначено частоту носійства різних варіантів гена АT1Р поліморфізмом із заміною аденіна на цитозин в 1166 положенні.

Встановлено, що у осіб чоловічої статі частота генотипу A1166А гена АТ1P складає 62,03\% (n=49), генотипу A1166C - 30,38\% (n=24), а генотипу C1166C $7,59 \%(n=6) \quad\left(p_{a a-c c} \leq 0,05 ; p_{a c-c c}>0,05 ; p_{a c-a а} \leq 0,05\right)$. При вивченні частотного розподілу алелей гена АT1P було встановлено, що серед чоловіків без серцевосудинної патології алель А зустрічається у $75,16 \%$ осіб, алель С - у 24,84\%. При порівнянні частот алелей гена АТ1Р також виявлені достовірні розбіжності $(p<0,05)$. Таким чином, у чоловіків без серцевосудинної патології переважає генотип А1166А гена AT1P (Рис. 1). Подібну частоту зустрічаємості поліморфних генів AT1P та алелей відзначали у мешканців Поділля і раніше $[1,2,10,11,12]$. 
ToM 22, N 1-2 2018 p.

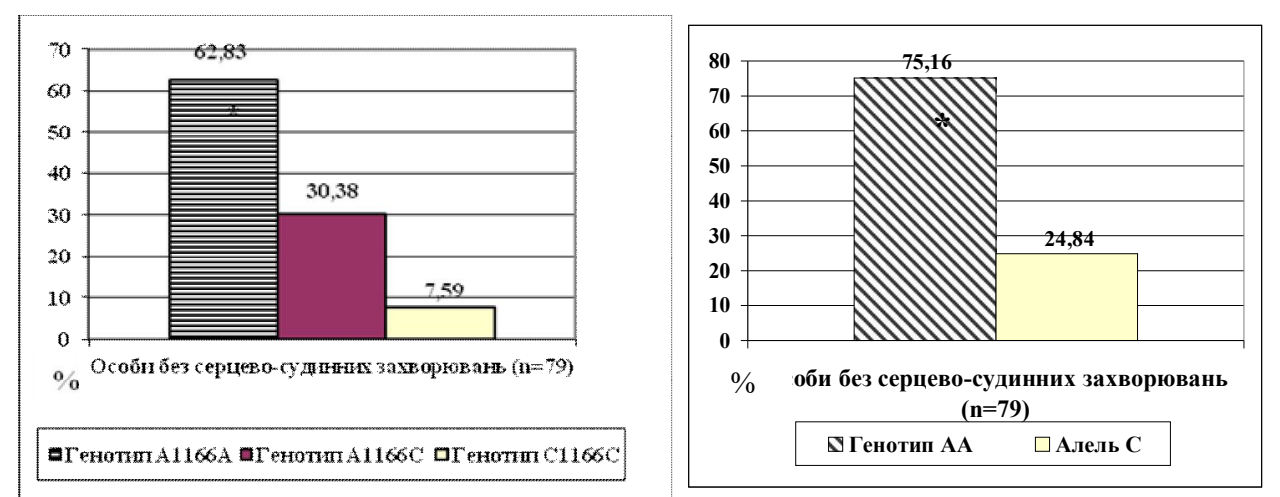

Рис. 1. Розподіл частот генотипів та алелей гена АТ1Р серед чоловіків без серцево-судинної патології 40-60 років мешканців Подільського регіону, (\%).

Примітка: різниия показників достовірна $(p \leq 0,05)$ при порівнянні з: * - генотипом A1166C/алеллю С в межах групи.

Подібний зв'язок виявлений у жителів Москви алель А та генотип AА гена AT1P зустрічається значно частіше у практично здорових людей [15]. У представників французької популяції алель А також достовірно частіше виявлялась серед осіб без серцево-судинної патології [25]. Є дані, що для японської популяції існує асоціація між носійством СС-генотипу та підвищеним індексом маси міокарда ЛШ як при нормальному АТ, так і у гіпертензивних осіб [24]. Кореляція носійства генотипу СС 3 розвитком АГ знайдена і у китайській популяції [19]. В Україні також проводились дослідження серед мешканців Полтави хворих на гіпертонічну хворобу частота виявлення генотипів АС та СС вдвічі більша, а питома вага носіїв генотипу $A A$ у 4 рази менша $(p \leq 0,05)$ у порівнянні зі здоровими особами. Подібний зв'язок розвитку неускладненої ГХ з поліморфізмом АТ1Р серед чоловіків зрілого віку, мешканців Вінницької області прослідковувався у дослідженні проведеному співробітниками кафредри внутрішньої медицини медичного фракультету №2 ВНМУ імені М.І. Пирогова. Як і у жителів Полтави, у мешканців Вінниччини була доведена достовірно більша частота розповсюдженості генотипів A1166C та C1166C та алелі С у хворих з ГХ. Також встановлена асоціація носійства генотипу A1166C та алелі С у хворих на ГX із формуванням вираженої ЕГЛШ, систолічної та діастолічної дисфункцій міокарда ЛШ та фрормуванням ХCH $[11,12]$.

Встановлено, що у жінок без серцево-судинної патології переважає генотип A1166A гена AT1P, а успа- дкування жінками постменопаузного віку мешканок м. Вінниці та Вінницької області, генотипів гена АT1P із наявністю алелі C - A1166C та C1166C, асоціюється 3 вищою ймовірністю виникнення ХСН II А стадії ІІ-ІІІ ФК за NYHA на тлі ГХ [10].

За нашими даними у носіїв генотипу A1166A виявлено достовірно меншу частоту зустрічаємості обтяженої спадковості порівняно з носіями алелі С (20,61\% і 83,33\% відповідно).

Отже, поліморфізм AT1R $€$ фактором, який може бути використаним для пошуку можливої безсимптомної диссункції міокарду асоціації патології з активацією РААС. Відповідно, як зазначалось вище, з таким поліморфізмом очікуються зміни в концентрації біомаркерів, які відображають активність систем протидії РАAC (МНП) або наслідки її впливу. На структурну морфологію міокарду зокрема на процеси у сполучній тканині, які певною мірою відбиває концентрація галектину-3.

Враховуючи фактори які можуть відбивати активацію РААС було досліджено зміни частоти зустрічаємості різних категорій АТ (в рамках «нормальних величин»).

У носіїв алелі А оптимальний АТ зустрічається у $26,03 \%$ (1) осіб, нормальний АТ - 49,32\% (2), високий нормальний АТ - $24,65 \%$ (3) $\left(p_{2-1}<0,05, p_{3-1}>0,05\right.$, $\left.\mathrm{p}_{3-2}<0,05\right)$. У носіїв алелі С оптимальний АТ визначається у $33,33 \%$ (1) чоловіків, нормальний АТ - $16,67 \%$ (2), високий нормальний АТ - $50 \%$ (3) ( $\mathrm{p}_{2-1}<0,05$, $\left.\mathrm{p}_{3-1}>0,05, \mathrm{p}_{3-2}>0,05\right)$. Отже, у носіїв алелі С високий нормальний АТ виявляється вірогідно частіше, ніж у носіїв алелі А гена АT1P (p<0,05). (Рис. 2).

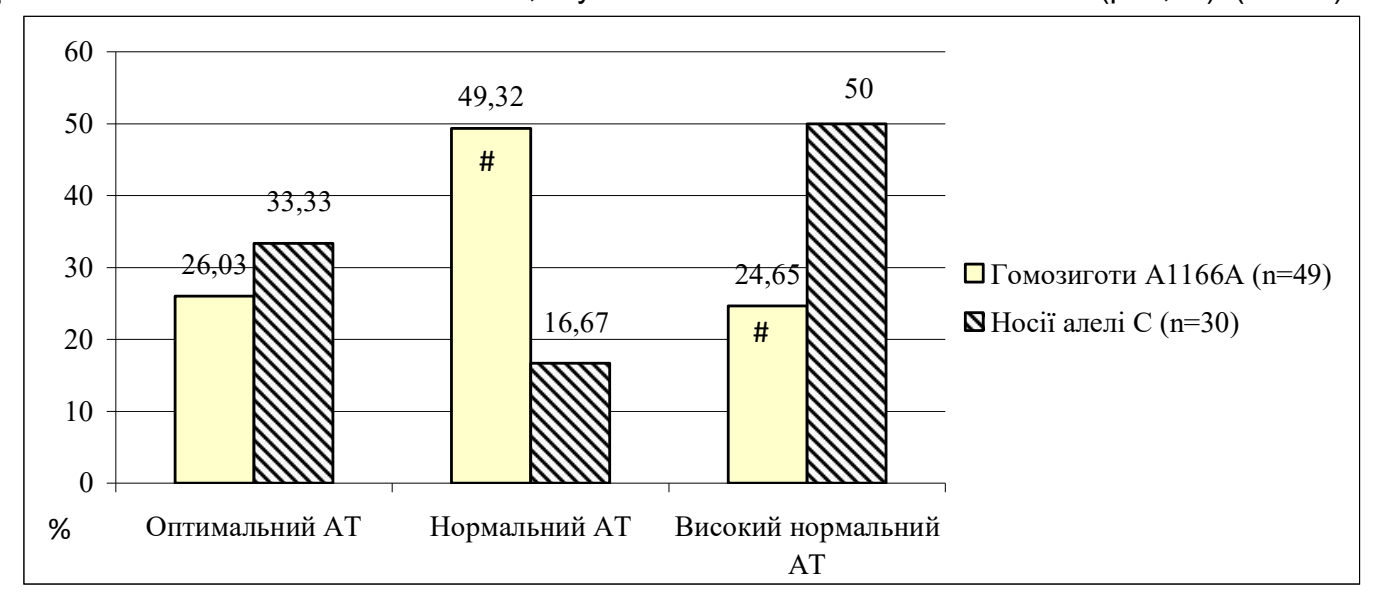

Puc. 2. Частота розподілу окремих категорій нормального АT у чоловіків без серцево-судинної патології 40-60 років мешканців Подільського регіону, носіїв різних алелей гена АT1P, (\%).

Примітки: різниця показників достовірна $(p<0,05)$ при порівнянні з: \# - оптимальним $A T$ в межах групи носіїв алелі $C$ гена AT1P. 
В результаті проведеного дослідження було визначено що при носійстві алелі С реєструється найвищий середній показник систолічного артеріального тиску (САТ).

Цікавим виявився той факт, що рівень галектину-3 у чоловіків без серцево-судинної патології, при різних категоріях нормального АТ були суттєво відмінними. Зокрема концентрація галектину-3 на відміну від вмісту МНП у осіб з нормальним та високим нормальним АТ була вищою ніж при оптимальному АТ. (Рис.3).

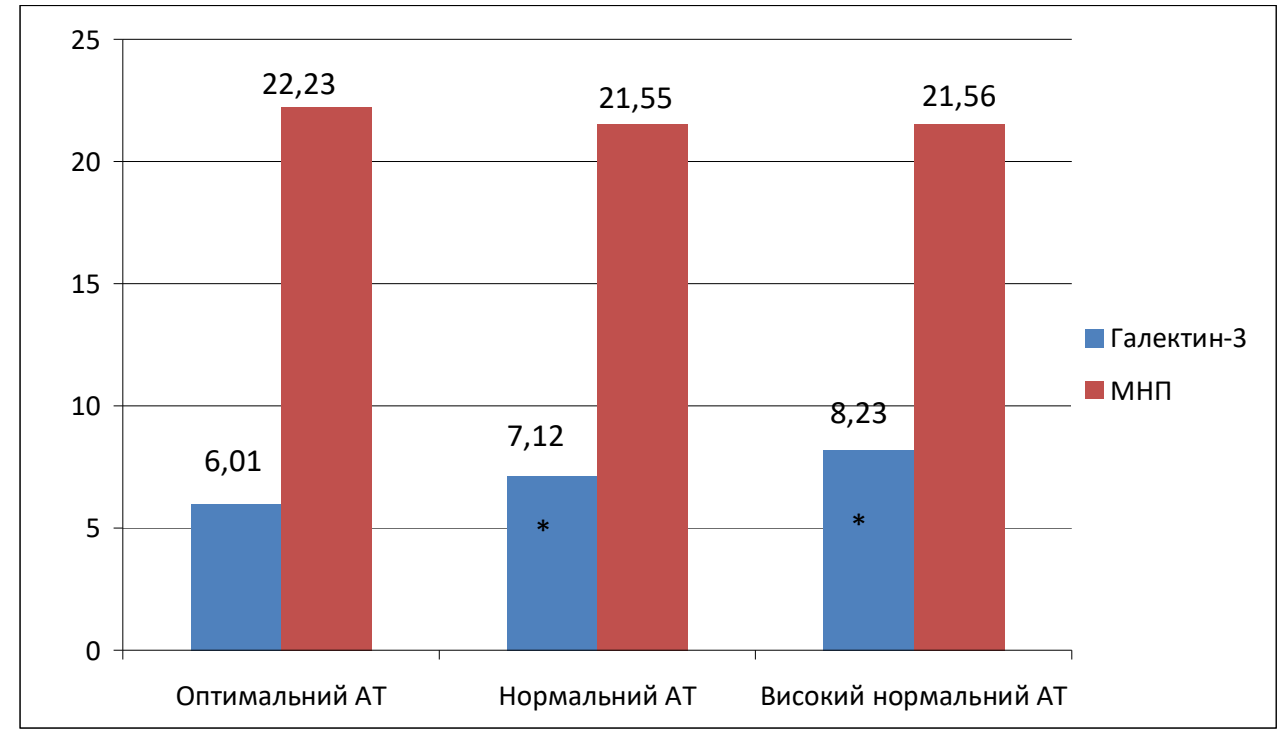

Puc. 3. Рівень галектину-3 та мозкового натрійуретичного пептиду в плазмі крові у чоловіків без серцево-судинної патології, носіїв різних генотипів гена AT1R при різних категоріях нормального АT (нг/мл; пг/мл).

Примітка: різниия показників достовірна $(p \leq 0,05)$ при порівнянні з:

* - в межах групи при різних категоріях АТ для показників галектину-3.

За даними літератури відома залежність концентрацій МНП в плазмі крові та ожиріння при ХСН було вирішено дослідити рівні плазмової концентрації галектину-3 та МНП у чоловіків без серцево-судинної патології при різному IMT. Достовірної різниці в рівнях МНП при наявності або відсутності ожиріння не виявлено ( $p>0,05)$, що відповідає результатам досліджень які проведено раніше [1].

На відміну від МНП, рівень галектину-3 при надмірній масі тіла становив - $(7,31 \pm 0,27)$ нг/мл $(\mathrm{n}=29)$, а при нормальній масі тіла відповідно - $(6,40 \pm 0,36)$ нг/мл $(n=50) \quad(p<0,05)$. Таким чином при проведенні досліджень $з$ використанням галектину-3 потрібно враховувати знайдений феномен.

\section{Висновки}

1. Серед чоловіків, мешканців Подільського регіону України 40-60 років без серцево-судинної патології переважає генотип A1166A гена AT1P .

2. Рівень галектину-3 та МНП у дослідженій популяції суттєво не залежав від носійства певного варіанту гена AT1P.

3. Концентрація галектину-3 у чоловіків без ознак серцево-судинної патології з нормальним та високим нормальним АТ була вищою ніж при оптимальному AT.

4. Рівень галектину-3 на відміну від МНП в плазмі крові вищий при надмірній масі тіла.

\section{Перспективи подальших розробок}

1. $€$ досить актуальним вивчення фенотипових маркерів, як найбільш простих, доступних і прийнятних в практичній діяльності лікаря критеріїв ризику розвитку ГХ.

2. Зрозуміло виникає питання змін концентрації галектину-3 в сполученні з МНУП при успадкуванні різних варіантів АТ1Р, враховуючи асоціацію останніх з тими ж самими процесами в міокарді від яких може залежати вміст в плазмі крові цього біомаркеру.

\section{Література}

1. Бланар О. Л. Особливості продукції В-натрійуретичного пептиду у осіб з ожирінням.. Матеріали Всеукраїнської науково-практичної конференції з міжнародною участю «Сучасні проблеми терапії: від гіпотез до фрактів»: 2005 Тези доповідей, 346.

2. Бланар О. Л. Спадковість та структурно-функціональні зміни серця у хворих на гіпертонічну хворобу, ускладнену серцевою недостатністю // Сімейна медицина. 2009. - № 2. - С. 79-85.

3. Гефтер, Ю.О. Стан міокарду у хворих на гіпертонічну хворобу в залежності від варіанту генотипу рецепторів ангіотензину II 1-го типу та наявності судинних ускладнень // Галицький вісник. - 2006. - № 1 (13). - С. 20-24.

4. Драпкина, О. М. Применение биологических маркеров В диагностике диастолической сердечной недостаточности // Журнал Сердечная недостаточность. - №12 (6). C. 364-372.

5. Коваленко В.М., Камінський О.Г. Академік М.Д.Стражеско і розвиток вітчизняної кардіології та ревматології. - 2001: Київ. МОРІОН.

6. Коваленко В.М., Корнацький В.М. Динаміка стану здоров'я народу України та регіональні особливості. 2009, Аналітично-статистичний посібник. Київ. Медінформ.

7. Коваленко В.Н., Талаева Т.В. Сердечно-сосудистые заболевания и ренин-ангиотензиновая система.- 2013, Київ. Морион.

8. Корнацький В.М., Дорогой А.П., Манойленко Т.С. Серцево-судинна захворюваність в Україні та рекомендації щодо покращання здоров'я в сучасних умовах. -2012 , Київ.

9. Лозинський, С.Е. Роль поліморфізму А1166C гена рецепторів до ангіотензину-ІІ першого типу (ATP1) у виникненні артеріальної гіпертензії та гіпертрофії лівого шлуночка у мешканців Поділля // Общая медицина. 2012. -№ 5. - С. 87-101. 
10. Сакович О. О. Успадкування поліморфних генотипів гена рецептора ангіотензину II 1-го типу та фактори ризику розвитку гіпертонічної хвороби у жінок, які проживають у Вінницькій області // Запорожский медицинский журнал. - 2011. - №4(13). С. 44-47.

11. Старжинська, О.Л. Особливості перебігу гіпертонічної хвороби у чоловіків з різними генотипами рецептора ангіотензину II 1-го типу // Biomedical and Biosocial Antropology/ - 2005. - №4. - C. 171-177.

12. Старжинська О.Л. (2013). Поліморфізм генів ренінангіотензин-альдостеронової системи в кардіології. // Biomedical and biosocial anthropology. - 2013. - № 20. C. 204-207.

13. Токарь, А.В., Ена Л.М. Артериальная гипертензия в пожилом и старческом воздасте. 1989, Киев. Здоровье.

14. Целуйко, В.Й. Галектин-3 у хворих на хронічну серцеву недостатність // Український кардіологічний журнал. 2014. - № 3. -.С. 77-81.

15. Чистяков Д.А. Полиморфизм гена сосудистого рецептора ангиотензина II и седечно-сосудистые заболевания // Терапевтический архив. - 2000. - № 4. - С. 2730.

16. De Boer R.A. Galectin-3: a novel mediator of heart failure development and progression // Eur J Heart Fail. -2009. №11, 811-817.

17. De Filippi, C.R. Galectin-3 in heart failure - linking fibrosis, remodeling, and progression. US // Cardiology. - 2010. Vol.7. - P. 67-70

18. Edelmann, F. Galectin-3 in patients with heart failure with preserved ejection fraction: results from the Aldo-DHF // European Journal of Heart Failure. - 2015. - Vol.17. - P. 214-223.

19. Feng, X. A systematic review and meta-analysis of the association between angiotensin II type 1 receptor A1166C gene polymorphism and myocardial infarction suscepyibility // Journal of Renin-Angiotensin-Aldosterone System. - 2012. - Vol.23. - P. 1-9.
20. Milting, H. (2008). Plasma biomarkers of myocardial fibrosis and remodeling in terminal heart failure patients supported by mechanical circulatory support devices // J Heart Lung Transplant. - 2008. - Vol.27. - P. 589-596.

21. Poirier, O. (1998). New polymorphisms of the angiotensin II type 1 receptor gene and their associations with myocardial infarction and blood pressure: the ECTIM study. Etude Cas-Temoin de l'Infarctus du Myocarde // J. Hypertens. -1998. - Vol.10. - P.- 1443-1447.

22. Roig E.(2000). Clinical implications of increased plasma angiotensin II despite ACE inhibitor therapy in patients with congestive heart failure. // Eur Heart J. - 2000 Vol.21(1). - P. 53-57.

23. Suarez, G. Heart failure and galectin 3. // Annals of Translational Medicine. - 2014. -Vol. 2 (9). - P. 86-92.

24. Takami, S. Angiotensin II type 1 receptor gene polymorphism is associated with increase of left ventricular mass but not with hypertension. // Am. J. Hypertension. -1998. Vol. 11. - P. 316-321.

25. Tiret L.,Blanc H., Ruidavets J.B. et al. Gene polymorphisms of the rennin-angiotensin system in relation to hypertension and parental history of myocardial infarction and stroke: PEGASE study. Project d'Etude des Genes de l'Hypertension Arterielle Severe a Moderee Essentielle // J Hypertens.-1998.- Vol.16. - P. 37-44.

26. E.Wilson Grandin. Galectin-3 and the Development of Heart Failure after Acute Coronary Syyndrome: Pilot Experience from PROVE IT-TIMI 22. // Clinical Chemistry. 2012. - Vol. 58(1). - P. 267-273.

27. Yancy C.W. 2013 ACCF/AHA guideline for the management of heart failure: a report of the American College of Cardiology Foundation/American Heart Association Task Force on Practice Guidelines. // J. Am. Coll. Cardiol, 2013. - Vol.62(16). - P. 147-239.

Матеріал надійшов до редакції 22.02.2018 